\title{
Discovery of a Highly Selective STK16 Kinase Inhibitor
}

Feiyang Liu ${ }^{1,2,6}$, Jinhua Wang ${ }^{3,6}$, Xingxing Yang ${ }^{1,6}$, Binhua $\mathrm{Li}^{1,4,6}$, Hong $\mathrm{Wu}^{1,2}$, Shuang $\mathrm{Qi}^{1,4}$, Cheng Chen ${ }^{1,4}$, Xiaochuan $\mathrm{Liu}^{1,2}$, Kailin $\mathrm{Yu}^{1,2}$, Wenchao Wang ${ }^{1,4}$, Zheng Zhao, ${ }^{1,4}$ Aoli Wang $^{1,2}$,Yongfei Chen ${ }^{1,4}$, Li Wang ${ }^{1,4}$, Nathanael S.Gray ${ }^{3}$, Jing Liu ${ }^{1,4^{*}}$, Xin Zhang ${ }^{1 *}$, Qingsong $\mathrm{Liu}^{1,2,4,5^{*}}$

1. High Magnetic Field Laboratory, Chinese Academy of Sciences, 350 Shushanhu Road, P.O. Box 1110, Hefei, Anhui 230031, P. R. China

2. University of Science and Technology of China, Anhui, Hefei, 230036, P. R. China

3. Department of Biological Chemistry \& Molecular Pharmacology, Harvard Medical School, 250 Longwood Ave, SGM 628, Boston, MA 02115, USA

4. CHMFL-HCMTC target therapy Joint Laboratory, Shushanhu Road, Hefei 230031, Anhui, P. R. China

5. Hefei Science Center, Chinese Academy of Sciences, Shushanhu Road, Hefei 230031, Anhui, P. R. China

6. These authors contributed equally

${ }^{*}$ Correspondence:

jingliu@hmfl.ac.cn (JL), xinzhang@hmfl.ac.cn (XZ), qsliu97@hmfl.ac.cn (QL) 


\section{Supplemental materials:}

\section{Chemistry:}

\section{Chemical synthesis and characterization of STK16-IN-1}
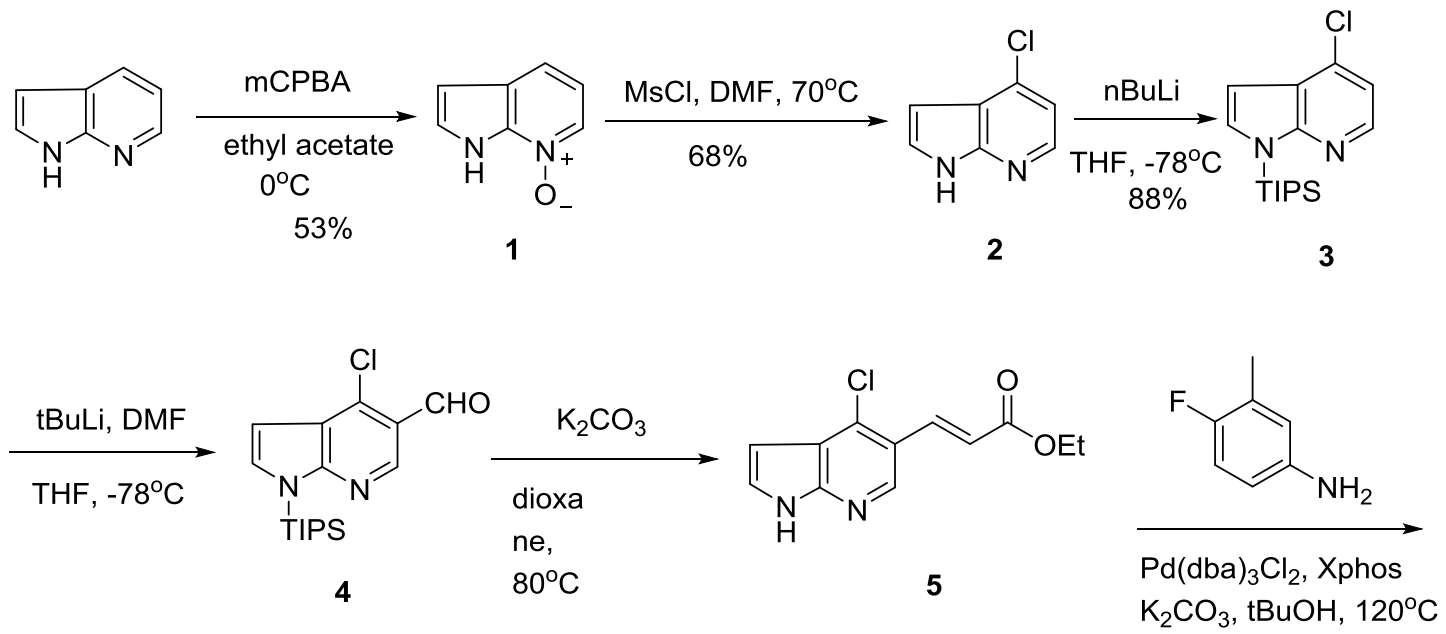<smiles>CCOC(=O)/C=C/c1cnc2[nH]ccc2c1Nc1ccc(F)c(C)c1</smiles><smiles>Cc1cc(-n2c(=O)ccc3cnc4[nH]ccc4c32)ccc1F</smiles>

General information: All chemicals were purchased from Sigma Aldrich. Anhydrous solvents and other reagents were purchased and used without further purification. The NMR data were obtained from Bruker $400 \mathrm{MHz}$. The purity of all compounds was $\geq 95 \%$. The purity was analyzed on an Agilent LC-MS Symmetry (C18 column, $4.6 \times 50 \mathrm{~mm}, 5 \mathrm{NM}$ ) using a gradient of 5-90\% acetonitrile in water containing $0.05 \%$ trifluoacetic acid (TFA) over $8 \mathrm{~min}(10 \mathrm{~min}$ run time) at a flow rate $2 \mathrm{~mL} / \mathrm{min}$.

1H-pyrrolo[2,3-b]pyridine 7-oxide (1) To a solution of $1 H$-pyrrolo[2,3-b]pyridine $(2.0 \mathrm{~g}, 16.93 \mathrm{mmol})$ in ethyl acetate $20 \mathrm{~mL}$ cooled with ice bath was added a solution of mCPBA (3.56 g, $20.65 \mathrm{mmol})$ in ethyl acetate $30 \mathrm{~mL}$ over about $1 \mathrm{~h}$. The resulting mixture was warmed to room temperature and allowed to stir until the starting azaindole hade been consumed (as judged by LC-MS analysis). The mixture was then cooled to $0^{\circ} \mathrm{C}$, the resulting slurry was filtered to collect the $\mathrm{N}$-oxide as the 
meta-chlorobenzoic acid (mCBA) addition salt 1', which then washed with ethyl acetate and dried.

A slurry of 1' in deionized water at room temperature was treated with a saturated $\mathrm{K}_{2} \mathrm{CO}_{3}$ aqueous to raise the $\mathrm{pH}$ to $9 \sim 10$. More water was added and stirred at room temperature for $1 \mathrm{~h}$. The slurry was cooled down to $0^{\circ} \mathrm{C}$ and stirred at this temperature for $2 \mathrm{~h}$, and then filtered to afford the precipitate. The precipitate was then washed with water and dried to afford 1 (white solid, $1.2 \mathrm{~g}, 53 \%$ yield). ${ }^{1} \mathrm{H}$ NMR (400 MHz, DMSO) $\delta 12.51(\mathrm{~s}, 1 \mathrm{H}), 8.16(\mathrm{~d}, J=5.9 \mathrm{~Hz}, 1 \mathrm{H}), 7.66(\mathrm{~d}, J=7.8 \mathrm{~Hz}, 1 \mathrm{H})$, $7.47(\mathrm{~s}, 1 \mathrm{H}), 7.08(\mathrm{~d}, J=13.8 \mathrm{~Hz}, 1 \mathrm{H}), 6.60(\mathrm{~s}, 1 \mathrm{H}) . \mathrm{MS}(\mathrm{ESI}): \mathrm{m} / \mathrm{z}(\mathrm{M}+\mathrm{H})^{+} 135$.

4-chloro-1H-pyrrolo[2,3-b]pyridine (2) A solution of $\mathbf{1}(1.2 \mathrm{~g}, 8.95 \mathrm{mmol})$ in DMF $10 \mathrm{~mL}$ was heated to $50^{\circ} \mathrm{C}$. Methanesulfonyl chloride $(3.08 \mathrm{~g}, 26.85 \mathrm{mmol})$ was added to the heated solution at such rate as to maintain the reaction temperature at below $75^{\circ} \mathrm{C}$. The mixture was heated at $80^{\circ} \mathrm{C}$, until the reaction was judged complete by LC-MS analysis. The mixture was cooled to room temperature and quenched with water. A solution of sufficient $10 \mathrm{~N} \mathrm{NaOH}$ aqueous was added to raise the $\mathrm{pH}$ to about 7 after cooling the quenched reaction mixture to $0^{\circ} \mathrm{C}$. The resulting mixture was warmed to room temperature and stirred for about $2 \mathrm{~h}$, then filtered to collect the product, which then washed with addition water, and dried under high vacuum at $45^{\circ} \mathrm{C}$, to afford 2 (white solid, $921 \mathrm{mg}, 68 \%$ yield). ${ }^{1} \mathrm{H}$ NMR (400 MHz, DMSO) $\delta$ $12.04(\mathrm{~s}, 1 \mathrm{H}), 8.18(\mathrm{~d}, J=5.1 \mathrm{~Hz}, 1 \mathrm{H}), 7.60(\mathrm{~d}, J=2.2 \mathrm{~Hz}, 1 \mathrm{H}), 7.20(\mathrm{~d}, J=5.1 \mathrm{~Hz}$, 1H), $6.51(\mathrm{~s}, 1 \mathrm{H}) . \mathrm{MS}(\mathrm{ESI}): \mathrm{m} / \mathrm{z}(\mathrm{M}+\mathrm{H})^{+} 153$.

4-chloro-1-(triisopropylsilyl)-1H-pyrrolo[2,3-b]pyridine (3) To a solution of 2 (921 $\mathrm{mg}, 6.06 \mathrm{mmol}$ ) in unhydrous THF $15 \mathrm{~mL}$, cooled at $-78^{\circ} \mathrm{C}$, was added slowly $\mathrm{n}-\mathrm{BuLi}$ (2.8 $\mathrm{mL}, 2.4 \mathrm{M}$ in hexane, $6.67 \mathrm{mmol})$. After stirring for $30 \mathrm{~min}$, the TIPSOTf ( $2 \mathrm{~mL}$, $6.67 \mathrm{mmol}$ ) was added. The mixture was allowed to rise to room temperature and stirred for $1 \mathrm{~h}$ until the reaction was judged complete by LC-MS analysis. The reaction mixture was quenched with water and was partitioned between hexanes and brine. The organic phase was washed with brine and dried over $\mathrm{MgSO}_{4}$, filtered and concentrated. The residue was column purified (eluting with hexane) to afford then title compound 3 (oil, $1.66 \mathrm{~g}, 88 \%$ yield). ${ }^{1} \mathrm{H}$ NMR (400 MHz, DMSO) $\delta 8.20$ (d, $J=$ 
$5.2 \mathrm{~Hz}, 1 \mathrm{H}), 7.60(\mathrm{~d}, J=3.5 \mathrm{~Hz}, 1 \mathrm{H}), 7.24(\mathrm{~d}, J=5.2 \mathrm{~Hz}, 1 \mathrm{H}), 6.68(\mathrm{~d}, J=3.5 \mathrm{~Hz}$, 1H), $1.86(\mathrm{t}, J=15.0 \mathrm{~Hz}, 3 \mathrm{H}), 1.06(\mathrm{~s}, 18 \mathrm{H}) . \mathrm{MS}(\mathrm{ESI}): \mathrm{m} / \mathrm{z}(\mathrm{M}+\mathrm{H})^{+} 309$.

4-chloro-1-(triisopropylsilyl)-1H-pyrrolo[2,3-b]pyridine-5-carbaldehyde (4) To a solution of 3 (1.66 g, $5.38 \mathrm{mmol})$ in unhydrous THF $15 \mathrm{~mL}$, cooled at $-78^{\circ} \mathrm{C}$, was added slowly sec-BuLi (8.3 mL, 1.3 M in hexane, $10.76 \mathrm{mmol})$. After stirring for $1 \mathrm{~h}$, then DMF $(1.3 \mathrm{~mL}, 16.14 \mathrm{mmol})$ was added at $-78^{\circ} \mathrm{C}$. The reaction solution was allowed to stir for $1.5 \mathrm{~h}$ and quenched with saturated $\mathrm{NH}_{4} \mathrm{Cl}$ aqueous. Then the mixture was warmed to room temperature and basified with saturated $\mathrm{NaHCO}_{3}$ aqueous to a $\mathrm{pH}$ of $8 \sim 9$ and extracted with ethyl acetate. The organic extracts was washed with brine, dried over $\mathrm{MgSO}_{4}$, filtered and concentrated to afford the crude product 4 (1.5 g), which was used to the next step without any further purification. MS (ESI): m/z (M+H) 337 .

Ethyl (E)-3-(4-chloro-1H-pyrrolo[2,3-b]pyridin-5-yl)acrylate (5) To a solution of 4 $(1.5 \mathrm{~g}, 4.46 \mathrm{mmol})$ in dioxane $30 \mathrm{~mL}$ was added $\mathrm{K}_{2} \mathrm{CO}_{3}(3.1 \mathrm{~g}, 22.3 \mathrm{mmol})$, ethyl 2-(diethoxyphosphoryl)acetate $(2.6 \mathrm{~mL}, 13.38 \mathrm{mmol})$. The mixture was heated and stirred at $80^{\circ} \mathrm{C}$ for overnight. Then the reaction solution was cooled at room temperature, diluted with ethyl acetate and washed with water, then brine. The organic phase was dried over $\mathrm{MgSO}_{4}$, filtered and concentrated. The residue was column purified to afford the title compound 5, light yellow solid, $1.2 \mathrm{~g}$. ${ }^{1} \mathrm{H}$ NMR (400 MHz, DMSO) $\delta 12.29$ (s, 1H), 8.79 (s, 1H), 8.01 (d, J = 16.1 Hz, 1H), $7.69-$ $7.61(\mathrm{~m}, 1 \mathrm{H}), 6.81(\mathrm{~d}, J=16.1 \mathrm{~Hz}, 1 \mathrm{H}), 6.58(\mathrm{~d}, J=3.4 \mathrm{~Hz}, 1 \mathrm{H}), 4.22$ (q, $J=7.1 \mathrm{~Hz}$, 2H), $1.24(\mathrm{t}, J=7.1 \mathrm{~Hz}, 3 \mathrm{H})$. MS (ESI): $\mathrm{m} / \mathrm{z}(\mathrm{M}+\mathrm{H})^{+} 251$.

\section{Ethyl (E)-3-(4-((4-fluoro-3-methylphenyl)amino)-1H-pyrrolo[2,3-b] pyridin-5-yl)} acrylate (6) To a solution of $5(1.2 \mathrm{~g}, 4.8 \mathrm{mmol})$ in $\mathrm{tBuOH} 50 \mathrm{~mL}$ degassed with $\mathrm{Ar}$ was added 4-fluoro-3-methylaniline (0.6 g, $4.8 \mathrm{mmol}), \mathrm{K}_{2} \mathrm{CO}_{3}(1.9 \mathrm{~g}, 14.4 \mathrm{mmol})$, $\mathrm{Pd}(\mathrm{dba}) \mathrm{Cl}_{2}(0.3 \mathrm{~g}, 0.24 \mathrm{mmol})$, Xphos $(0.1 \mathrm{~g}, 0.24 \mathrm{mmol})$. The mixture was heated and stirred at $120^{\circ} \mathrm{C}$ for overnight. The residue was resolved with ethyl acetate after the reaction mixture was cooled at room temperature and the solvent was removed in high vacuo. Then the organic phase was washed with water, brine, dried over $\mathrm{MgSO}_{4}$, filtered and concentrated. The residue was column purified to afford the title product 
6, as a solid, $270 \mathrm{mg}, 17 \%$ yield. ${ }^{1} \mathrm{H}$ NMR (400 MHz, DMSO) $\delta 11.61$ (s, 1H), 8.73 (s, 1H), $8.48(\mathrm{~s}, 1 \mathrm{H}), 7.98(\mathrm{~d}, J=15.9 \mathrm{~Hz}, 1 \mathrm{H}), 7.19-7.02(\mathrm{~m}, 3 \mathrm{H}), 6.48$ (d, $J=15.8 \mathrm{~Hz}$, 1H), $5.64(\mathrm{~d}, J=1.7 \mathrm{~Hz}, 1 \mathrm{H}), 4.16(\mathrm{dd}, J=14.1,7.1 \mathrm{~Hz}, 7 \mathrm{H}), 2.19(\mathrm{~s}, 3 \mathrm{H}), 1.24(\mathrm{t}, J=$ $7.0 \mathrm{~Hz}, 3 \mathrm{H}) . \mathrm{MS}(\mathrm{ESI}): \mathrm{m} / \mathrm{z}(\mathrm{M}+\mathrm{H})^{+} 340$.

\section{1-(4-fluoro-3-methylphenyl)-1,7-dihydro-2H-pyrrolo[2,3- $h][1,6]$ naphthyridin-2-}

one (STK16-IN-1) To a solution of $6(250 \mathrm{mg}, 0.73 \mathrm{mmol})$ in EtOH $20 \mathrm{~mL}$ degassed with Ar. was added $\mathrm{K}_{2} \mathrm{CO}_{3}(1.9 \mathrm{~g}, 14.4 \mathrm{mmol})$. The mixture was sealed tube, heated and stirred at $100^{\circ} \mathrm{C}$ for overnight. The residue was resolved with ethyl acetate after the reaction mixture was cooled at room temperature and the solvent was removed in high vacuo. Then the organic phase was washed with water, brine, dried over $\mathrm{MgSO}_{4}$, filtered and concentrated. The residue was column purified to afford the title product JWC-029, as a off-white solid, $42 \mathrm{mg}, 20 \%$ yield. ${ }^{1} \mathrm{H}$ NMR (400 MHz, DMSO) $\delta$ $12.04(\mathrm{~s}, 1 \mathrm{H}), 8.59(\mathrm{~s}, 1 \mathrm{H}), 8.18(\mathrm{~d}, J=9.5 \mathrm{~Hz}, 1 \mathrm{H}), 7.46-7.36(\mathrm{~m}, 2 \mathrm{H}), 7.31$ (d, $J=$

$3.4 \mathrm{~Hz}, 1 \mathrm{H}), 7.18(\mathrm{~s}, 1 \mathrm{H}), 6.59$ (d, $J=9.4 \mathrm{~Hz}, 1 \mathrm{H}), 4.50(\mathrm{~s}, 1 \mathrm{H}), 2.32(\mathrm{~s}, 3 \mathrm{H}) .{ }^{13} \mathrm{C}$ NMR (101 MHz, DMSO) $\delta 162.73,149.49,145.21,140.92,140.51,135.47,132.86$, $129.16,126.48,124.39,117.98,116.83,116.60,110.05,106.24,100.58,14.55 . \mathrm{MS}$ (ESI): $\mathrm{m} / \mathrm{z}(\mathrm{M}+\mathrm{H})^{+} 294$.

\section{Biology:}

\section{Cell culture}

MCF-7, HCT116, HeLa, MDA-MB-468, T47D cells were cultured in DMEM medium supplemented with $10 \%$ FBS and $1 \%$ penicillin/streptomycin $(\mathrm{P} / \mathrm{S})$. SKBr3 cells were cultured in DMEM/F12 medium supplemented with 10\% FBS and 1\% P/S. Mec-2, JVM-1, H1975 cells were cultured in RPMI1640 medium supplemented with $10 \%$ FBS and 1\% P/S. All cells were obtained from the American Type Culture Collection and incubated at $37^{\circ} \mathrm{C}$ in $5 \% \mathrm{CO}_{2}$.

\section{Reagents and antibodies}

AZD8055 were purchased from Sigma-Aldrich. Antibodies used for P-AKT (S473), P-AKT (T308), P-p70S6K (T389), P-4EBP1 (T37/46), P-4EBP1 (S65), P-4EBP1 
(T70), P-Threonine, P-Tyrosine, P-Serine, Total AKT, Total S6K, Total 4EBP1, PARP were purchased from Cell Signaling Technology. The Flag, STK16, $\beta$-actin and $\beta$-tubulin antibodies were from Sigma-Aldrich. DRG1 antibody was obtained from Santa-Cruz Biotechnology. The HRP-linked anti-mouse IgG antibody was from Cell Signaling Technology. The anti-fade prolong Gold with DAPI were from Molecular Probes. M-PER buffer were from Thermo Pierce. The FITC-anti-tubulin was obtained from Sigma-Aldrich. The siRNAs were ordered from Genepharm (Shanghai, China). Hiperfect was from Qiagen. Protease inhibitor and phosphatase inhibitor cocktails were purchased from Roche.

\section{STK16, 4EBP1 and DRG1 protein expression}

STK16 (residues 1-305) (GenBank accession number gi4505837) was subcloned into a pET-28a-derived vector in-frame with a sumo tag at the N-terminal. Full-length STK16 were expressed in E. coli (BL21 [DE3]) cells as previously described ${ }^{l}$. Proteins were purified by nickel-Sepharose affinity resin; sumo-tag was subsequently removed by overnight digestion of sumo protease at $16{ }^{\circ} \mathrm{C}$. Tag-free proteins were further purified on a HiTrapQ ion-exchange column and a Hiload 75 (GE Healthcare) gel-filtration column, then concentrated to $5 \mathrm{mg} / \mathrm{ml}$, snap frozen in $100 \mu \mathrm{l}$ aliquots, and stored at $-80^{\circ} \mathrm{C}$. Purified STK16 and all the mutants were homogeneous as assessed by SDS-PAGE and Western blotting. DRG1 construct was cloned into pGEX4T-1 and 4EBP1 construct was cloned into pET22a, both two proteins were expressed in E. coli (DE3) and purified by affinity chromatography.

\section{IP kinase assay}

STK16 and substrates 4EBP1 and DRG1 were purified as described above. Various concentrations of STK16-IN-1 were incubated with purified STK16 protein for 1 hour before kinase assays were performed for $30 \mathrm{~min}$ at $37{ }^{\circ} \mathrm{C}$ in a final volume of $30 \mu \mathrm{l}$ consisting of the kinase buffer (50 mM Tris, $\mathrm{pH} 7.4,20 \mathrm{mM} \mathrm{MgCl} 2,2.5 \mathrm{mM}$ DTT, 20 $\mu \mathrm{M}$ ATP) and $10 \mu \mathrm{M}$ of 4EBP1 or DRG1 as substrates. Reactions were stopped by the addition of sample buffer and boiled for 5 mins. Samples were subsequently 
analyzed by SDS-PAGE and immunoblotting.

\section{ATP competitive assay}

ADP-Glo ${ }^{\mathrm{TM}}$ assay kits from Promega Corporation were used according to instructions. STK16-IN-1 was generally prepared with 1:3 serial dilutions for 4 concentrations (100 nM, $50 \mathrm{nM}, 20 \mathrm{nM}$, and $10 \mathrm{nM}) ; 6$ concentrations were used $(1 \mathrm{mM}$ to $10 \mu \mathrm{M})$ for ATP competition experiments. The kinase reaction was performed with $1 \times$ kinase reaction buffer (40 $\mathrm{nM}$ Tris base $\mathrm{pH} 7.5,20 \mathrm{mM} \mathrm{MgCl}_{2}, 0.4 \mathrm{mM}$ DTT), $0.1 \mathrm{mg} / \mathrm{ml}$ BSA, distilled $\mathrm{H}_{2} \mathrm{O}$, substrate and STK16 kinases in a total assay volume of $5 \mu \mathrm{L}$ following the manufacturer's protocol. Reactions in each well were started immediately by adding ATP and kept going for half an hour under $37^{\circ} \mathrm{C}$. After the plate cooled for 5 minutes at room temperature, $5 \mu \mathrm{L}$ of ADP-Glo reagent was added into each well to stop the reaction and consume the remaining ADP within 40 minutes. At the end, $10 \mu \mathrm{L}$ of kinase detection reagent was added into the well and incubated for 1 hour to produce a luminescence signal. Luminescence was measured using an Envision multilabel plate reader (Envision, PerkinElmer, USA) with an integration time of $1 \mathrm{sec}$ per well.

\section{Molecular modeling}

Docking of the STK16-IN-1 to STK16 kinase was obtained using Autodock4.0. ${ }^{2}$ The STK16 kinase structure (PDB id: 2BUJ) including the chain A of the kinase domain was used as the receptor, and polar hydrogen atoms were added to the receptor structure. Small molecule STK16-IN-1 was constructed using the online-demo CORINA server. The grip map was adjusted as a dimension of $56 \times 60 \times 60$ points with a spacing of $0.375 \AA$. The default parameters were used and a total of 100 runs were performed with Lamarckian genetic algorithm. The docked modeling were then clustered and sorted by binding energy. 


\section{Immunofluorescence}

MCF-7 cells were grown on coverslips and treated with the compounds for 72 hours. Cells were washed once with PBS and fixed by $4 \%$ formaldehyde at room temperature for 20 mins. Then they were blocked by AbDil-Tx (TBS-Tx supplemented with $2 \% \mathrm{BSA}$ and $0.05 \%$ sodium azide) at room temperature for 30 mins, followed by FITC-anti-tubulin incubation at room temperature for 60 mins. Then washed by TBS-Tx (TBS added with $0.1 \%$ Triton $\mathrm{x}-100$ ) and mounted by anti-fade prolong Gold with DAPI. Images were taken by Leica (DMI4000B) fluorescent microscope. Representative images were shown in figures.

\section{HeLa-STK16-GFP-Flag stable cell line}

HeLa-STK16-GFP-Flag cells were established by infection of HeLa cells using MSCV virus inserted the indicated genes (STK16-GFP-Flag, Vsvg and PLMV) and screened by $1 \mu \mathrm{g} / \mathrm{ml}$ puromycin. Stable cell lines are maintained in medium containing $1 \mu \mathrm{g} / \mathrm{ml}$ puromycin.

\section{Immuno-precipitation experiment}

Hela-STK16-GFP-Flag and HCT-116 cells were treated with DMSO, $2.5 \mu \mathrm{M}, 5 \mu \mathrm{M}$ or $10 \mu \mathrm{M}$ of STK16-IN-1 for 3 hours before they are washed in PBS, harvested and lysed in M-PER buffer (life technologies) supplemented with protease and phosphatase inhibitors. The lysis procedure was done according to the manufacturer's instructions. FLAG or DRG1 antibody was coupled to dynabeads (Invitrogen) before it was added to cell lysates. After room temperature incubation for 20-30 minutes, dynabeads were washed thoroughly with PBS with $0.05 \%$ Tween-20 before sample buffer was added and boiled.

\section{Signaling pathway studies}

MCF-7, HCT-116 or HeLa cells were plated in 6-well plate overnight. Compounds of indicated concentrations were added into cells 2 hours before cells were lysed by 100 
$\mu 1$ of M-PER buffer supplemented with protease and phosphatase inhibitor cocktail at $4{ }^{\circ} \mathrm{C}$ for 20 mins. For Western Blotting, the whole cell lysate were mixed with $5 \times$ SDS loading buffer thoroughly and denatured at $95{ }^{\circ} \mathrm{C}$ for 5 mins. Equal amounts of protein $(10-50 \mu \mathrm{g})$ in cell lysates were separated by SDS-PAGE gel electrophoresis, transferred to polyvinylidene difluoride membranes (Millipore), immunoblotted with specific primary and secondary antibodies, and detected by chemiluminescence with the ECL Detection Reagents from Thermo Scientific Pierce®.

\section{RNAi knockdown of STK16}

MCF-7 cells were plated in 12-well or 24-well plate before they were treated with 40 nM STK16 siRNAs or negative control Hiperfect transfection reagent following manufacture's protocol. The siRNA sequence for STK16 was GGCCAACAUACUACCCAAATT. After 72 hours incubation, the cells were either lysed for Western Blotting or fixed to perform immunofluorescence experiments.

\section{Anti-proliferation Assay}

Cells were seeded in 96-well or 384-well culture plates. Various concentrations of compounds were added into plates for 72 hours. Cell viability was measured by the Cell Titer-Glo assay (Promega, USA), according to the manufacturer's instructions, and luminescence was measured in a multi-label reader (Envision, PerkinElmer, USA). Data were normalized to control groups (DMSO) and represented by the mean of three independent measurements with standard error $<20 \% . \mathrm{GI}_{50}$ values were calculated using Prism 5.0 (GraphPad Software, San Diego, CA).

\section{Cell cycle analysis}

MCF-7, HCT116 and HeLa cells were treated with STK16-IN-1 $(0,5,10 \mu \mathrm{M})$ for 72 hours. The cells were fixed in $70 \%$ cold ethanol and incubated at $-20{ }^{\circ} \mathrm{C}$ overnight then stained with PI/RNase staining buffer (BD Pharmingen). Flow cytometry was performed using a FACS Calibur (BD), and results were analyzed by ModFit software. 


\section{Apoptosis analysis}

MCF-7, HCT116, HeLa cells were treated with STK16-IN-1 $(0,5,10 \mu \mathrm{M})$ for 72 hours and apoptotic cells were analyzed by flow cytometry using Annexin V/PI apoptosis detection kit (BD Biosciences). For PARP and cleaved PARP examination by Western-blotting, MCF-7 cells were treated with the same concentrations used in anti-proliferation assay of STK16-IN-1 and chemotherapy or cytokinesis drugs for 72 hours before apoptotic cells were analyzed by Western blotting.

\section{Drug combination study}

Cells were plated in 96-well plate overnight. Serially diluted STK16-IN-1 and doxorubicin or cisplatin were added along or together to cells and incubated for 72 hours(The concentrations of different compounds were shown in Supplemental Fig. 5, representative data were shown in Fig. 2E). Cell viability was measured by the Cell Titer-Glo assay. CI index (Data not shown) was calculated by Calcusyn software (Biosoft, version 2.1), using the Chou-Talalay method (Chou and Talalay, 1984)

\section{Statistical analysis}

Results are mean values \pm standard error. Statistical analyses were performed by an unpaired, 2-tailed Student t-test.

\section{Reference}

(1) Eswaran, J., Bernad, A., Ligos, J. M., Guinea, B., Debreczeni, J. E., Sobott, F., Parker, S. A., Najmanovich, R., Turk, B. E., and Knapp, S. (2008) Structure of the human protein kinase MPSK1 reveals an atypical activation loop architecture. Structure 16, 115-124.

(2) Morris, G. M., Huey, R., Lindstrom, W., Sanner, M. F., Belew, R. K., Goodsell, D. S., and Olson, A. J. (2009) AutoDock4 and AutoDockTools4: Automated docking with selective receptor flexibility. $J$. Comput. Chem. 30, 2785-2791. 
Supplemental Fig. 1 STK16-IN-1 inhibitory activity against PI3K $\alpha, \beta, \delta, \gamma$ in the cell based assays.
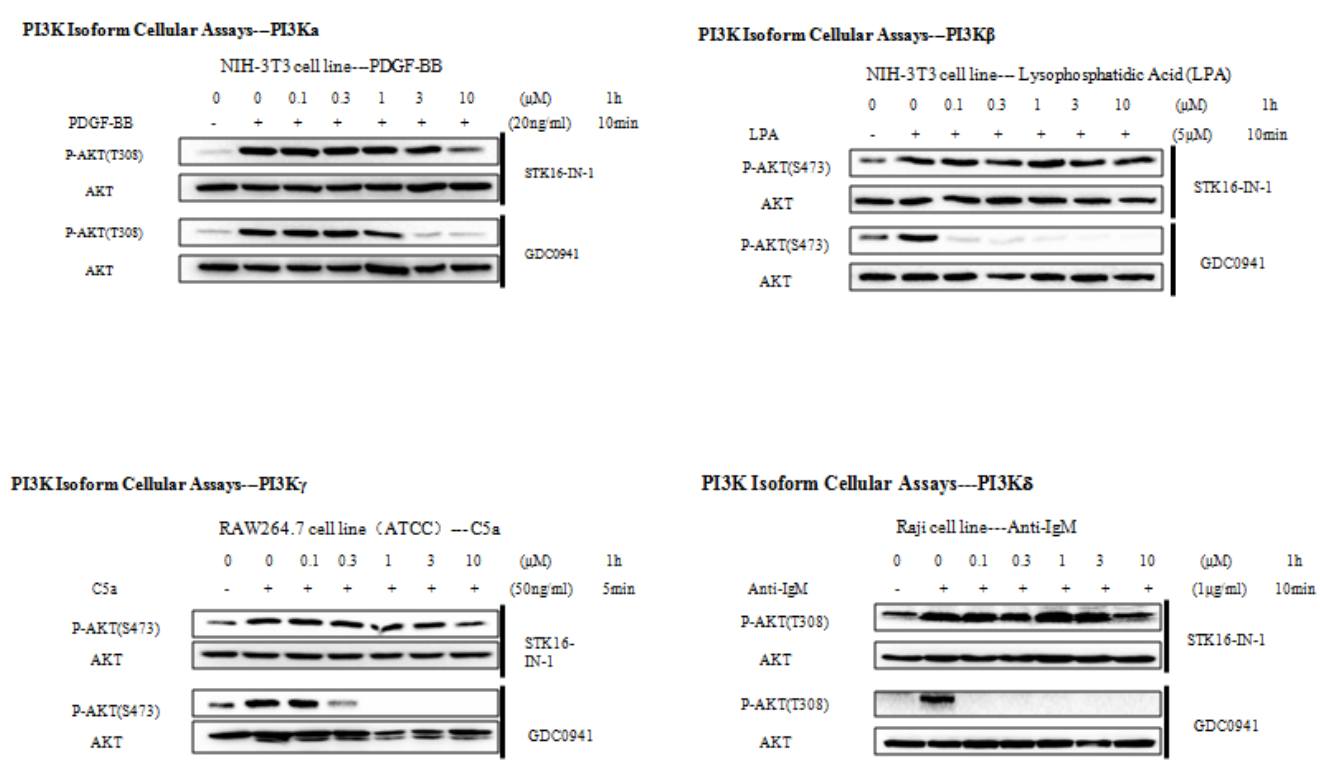

Supplemental Fig. 2 STK16 kinase protien expression in different cell lines.

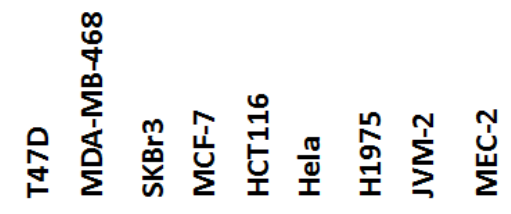

STK16

$\beta$-Actin 
ACS Chemical Biology Supplemental Materials

Supplemental Fig. 3 Apoptotic analysis of STK16-IN-1 in MCF-7, HCT-116, HeLa cells.

\begin{tabular}{|c|c|c|}
\hline & & \\
MCF-7 cell & AnnexinV+ Pl- & AnnexinV+PI+ \\
\hline & & \\
ctr & $4.33 \%$ & $9.52 \%$ \\
\hline STK16-IN-1 5uM & $8.69 \%$ & $18 \%$ \\
\hline & & \\
STK16-IN-1 10uM & $7.91 \%$ & $35.40 \%$ \\
\hline
\end{tabular}

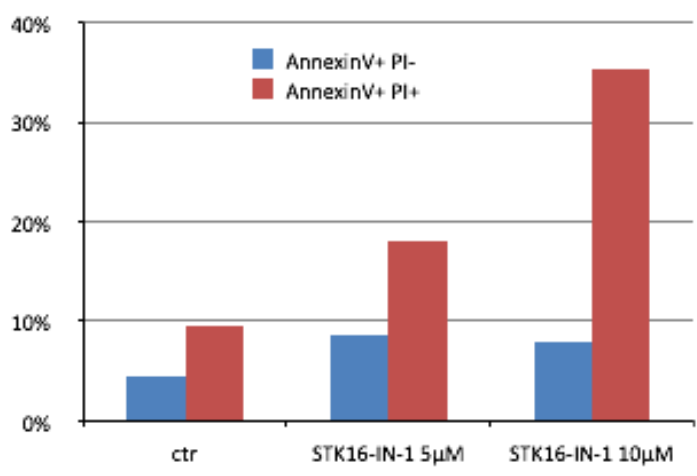

\begin{tabular}{|c|c|c|}
\hline HeLa cell & AnnexinV+PI- & Annexin $\mathrm{V}+\mathrm{Pl}+$ \\
\hline $\mathrm{ctr}$ & $4.05 \%$ & $10.90 \%$ \\
\hline STK16-IN-1 S $\mu \mathrm{M}$ & $15.80 \%$ & $42.60 \%$ \\
\hline STK16-IN-1 $10 \mu \mathrm{M}$ & $20.60 \%$ & $54.50 \%$ \\
\hline
\end{tabular}

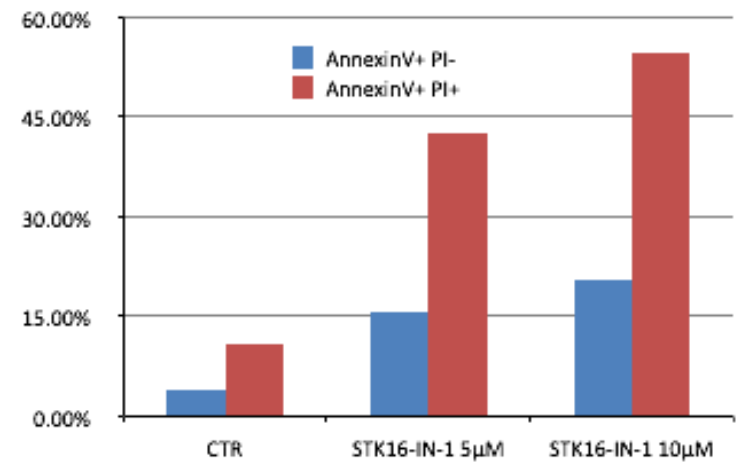

\begin{tabular}{|c|c|c|}
\hline HCT-116 cell & AnnexinV+PI- & AnnexinV+ $\mathrm{Pl}+$ \\
\hline ctr & $1.62 \%$ & $6.90 \%$ \\
\hline STK16-IN-1 SuM & $1.46 \%$ & $11.70 \%$ \\
\hline 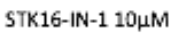 & $2.67 \%$ & $13.30 \%$ \\
\hline
\end{tabular}

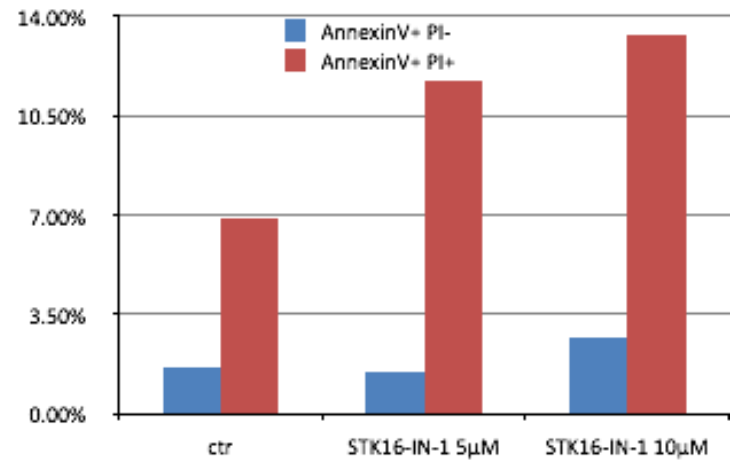


Supplemental Fig. 4 Immuno-precipitated and western blotting of DRG1's general threonine phosphorylation upon STK16-IN-1 treatment in HCT-116 cells.

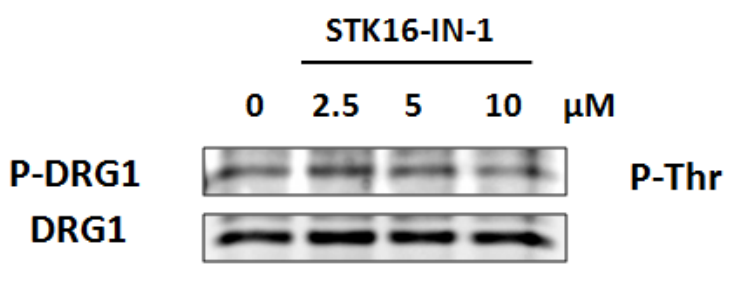

\section{HCT116 $2 \mathrm{~h}$ treatment}

Supplemental Fig. 5 Combination study of STK16-IN-1 with colchicine, paclitaxol, cisplatin or doxorubicin in MCF-7 cells by 72 hours Cell Titer-Glo assay.
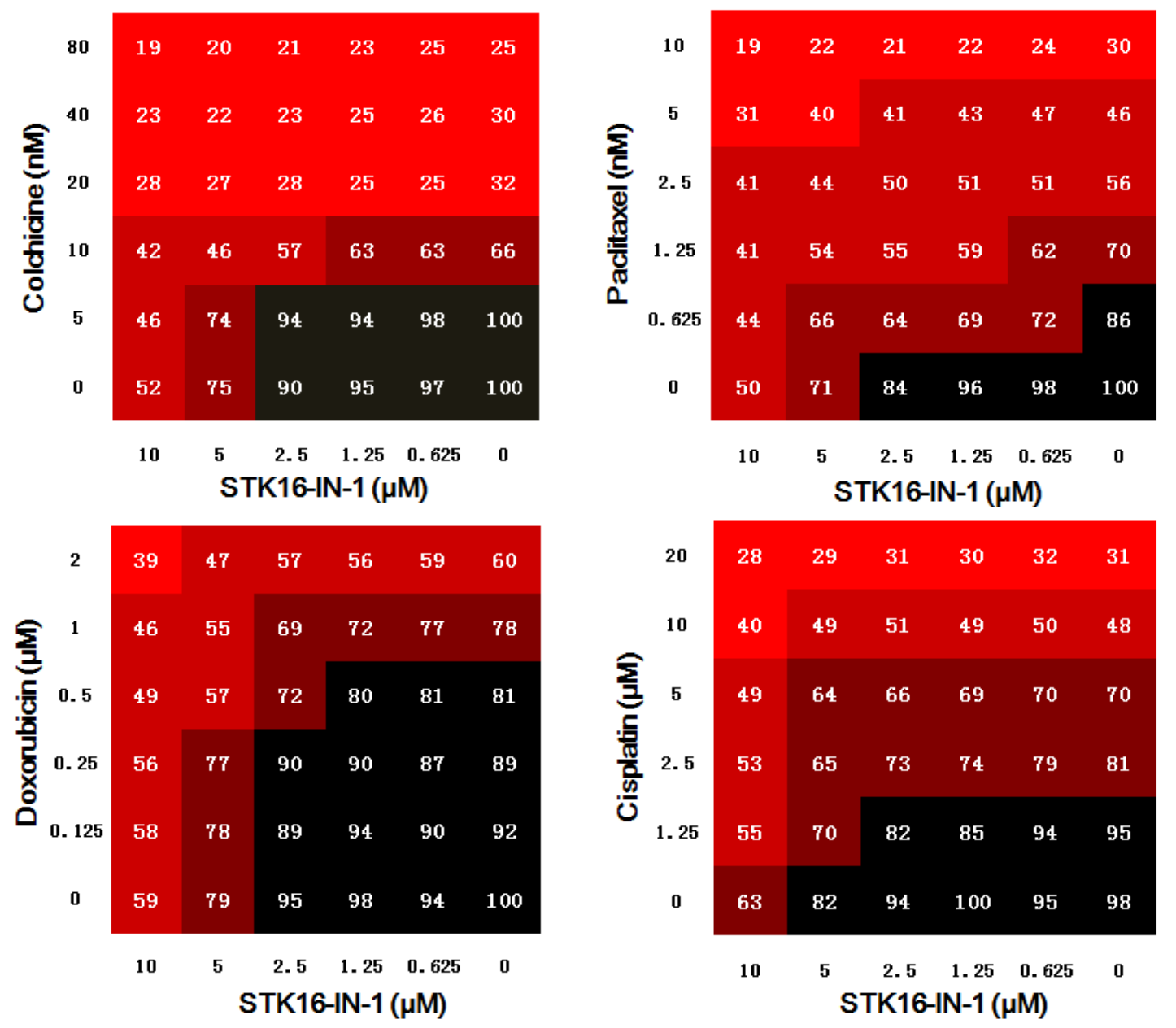
Supplemental Fig. 6 Western blotting detection of STK16, DRG1, 4EBP1 protein expression in HeLa, HCT-116 and MCF-7 cells.

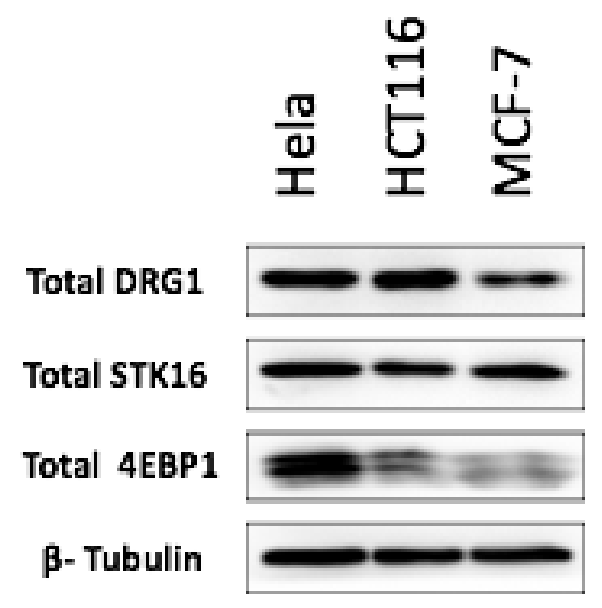


ACS Chemical Biology Supplemental Materials

Supplemental Fig. 7 FACS analysis of the cell cycle progression in MCF-7, HCT116 and HeLa cells.

MCF-7 72h
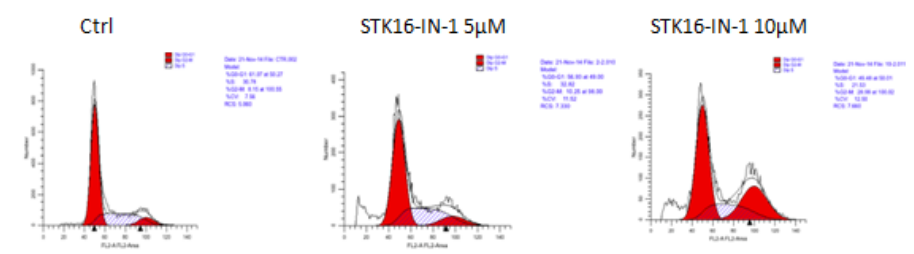

\begin{tabular}{|c|c|c|c|}
\hline & $\% G 0-G 1$ & $\% \mathrm{~s}$ & $\% G 2-M$ \\
\hline $\mathrm{Ctr}$ & 61.07 & 30.78 & 8.15 \\
\hline 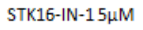 & 56.93 & 32.82 & 10.25 \\
\hline STK16-IN-1 $10 \mu \mathrm{M}$ & 49.48 & 21.53 & 28.99 \\
\hline
\end{tabular}

HCT116 $72 \mathrm{~h}$

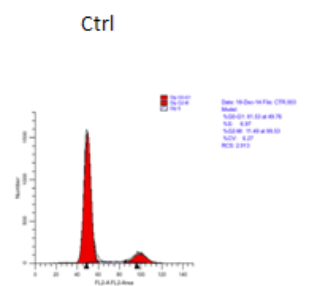

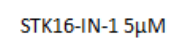

STK16-IN-1 10 $\mu \mathrm{M}$
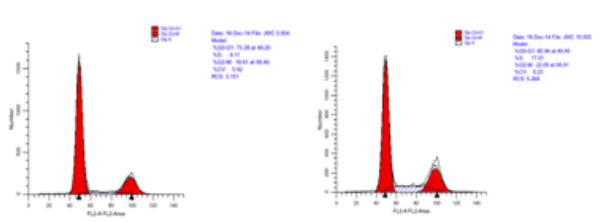

\begin{tabular}{|c|c|c|c|}
\hline & $\%$ G0-G1 & $\% \mathrm{~S}$ & $\% G 2-M$ \\
\hline $\mathrm{Ctr}$ & 81.53 & 6.97 & 11.49 \\
\hline 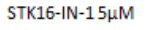 & 73.28 & 8.11 & 18.61 \\
\hline 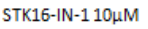 & 60.94 & 17.01 & 22.05 \\
\hline
\end{tabular}

Hela $72 \mathrm{~h}$

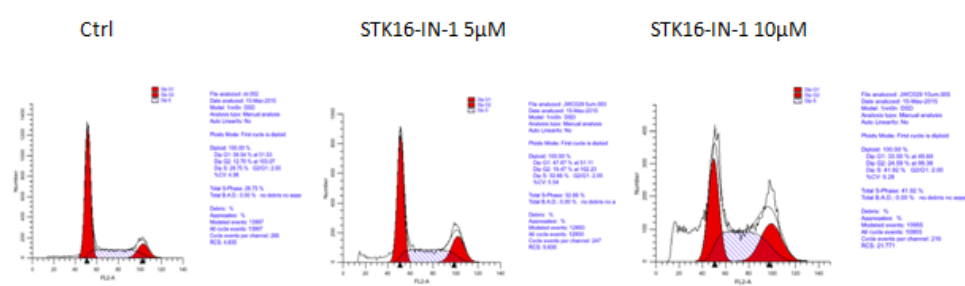

\begin{tabular}{|c|c|c|c|}
\hline & $\% G 0-G 1$ & $\% \mathrm{~s}$ & $\% G 2-M$ \\
\hline Ctr & 58.54 & 28.75 & 12.7 \\
\hline STK16-IN-15 $5 \mathrm{M}$ & 47.87 & 32.66 & 19.47 \\
\hline STK16-IN-110 $\mathrm{MM}$ & 33.5 & 41.92 & 24.59 \\
\hline
\end{tabular}


Supplemental Fig. 8 RNAi knockdown of STK16 kinase in HeLa Cells.

\section{STK16 RNAi reduces total cell number and increases binucleated cell percentage}

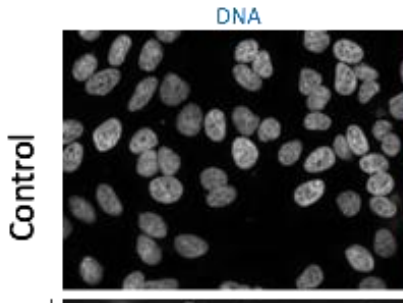

Merge with whole cell stain
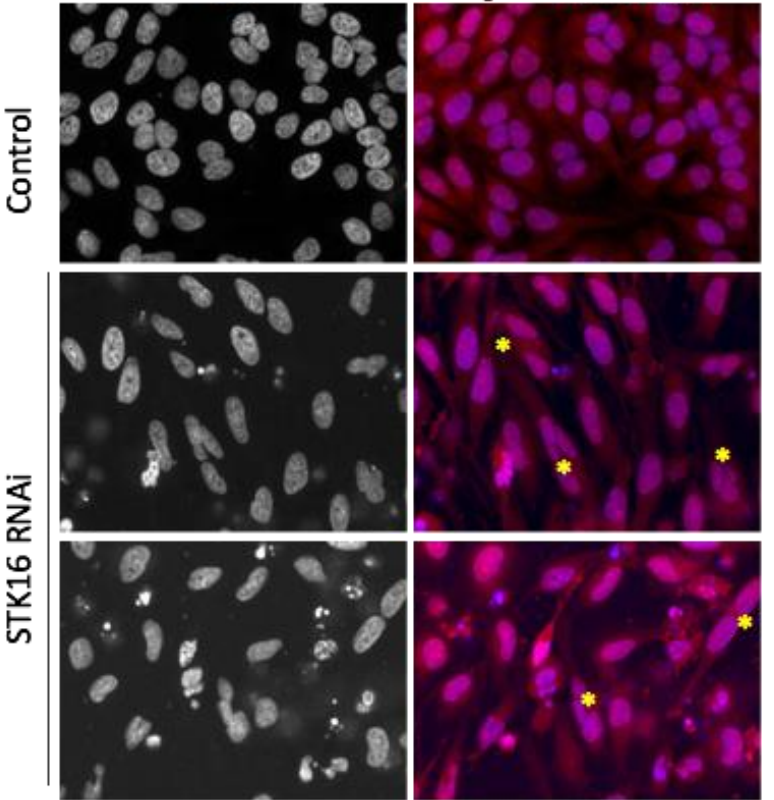

* Indicate binucleated cells

Relative total cell number

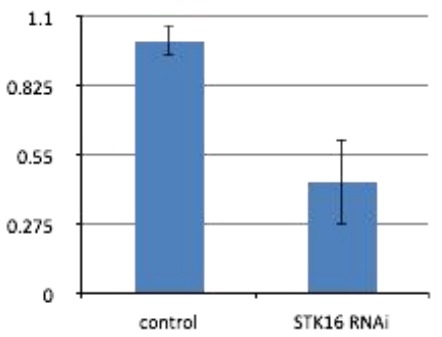

Relative \% of binucleated cell

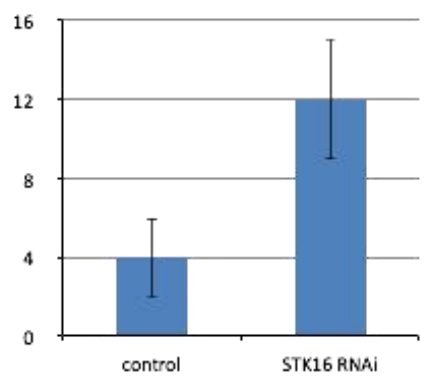

HeLa cell 
Supplemental Fig. 9 STK16-IN-1 inhibitory effect against a variety of mutants in the ATP binding pocket in STK16 kinase.

\section{STK16 drug resistant mutation}

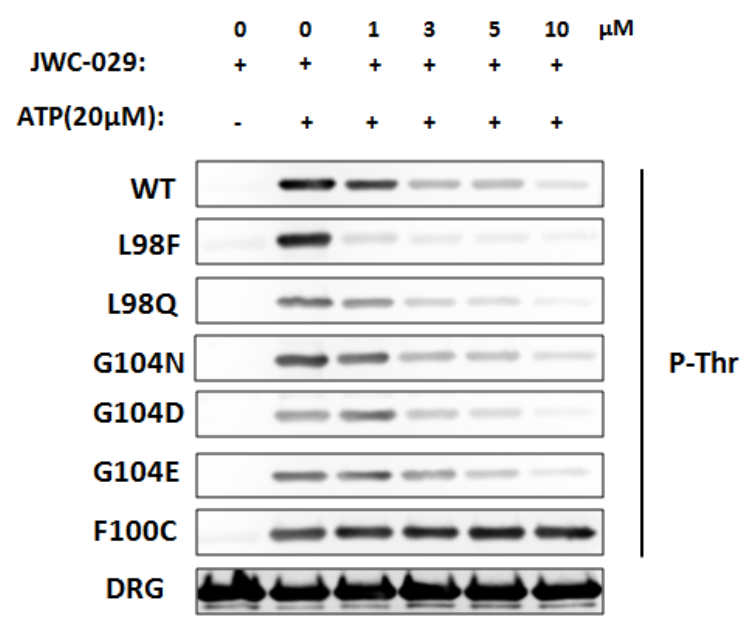

Supplemental Table 1 Kinomewide selectivity profiling of STK16-IN-1 with DiscoveRx KinomeScan ${ }^{\mathrm{TM}}$ technology (attached as a separate excel fil 